\title{
Syntaxonomy of plant communities with diagnostic species of genus Elytrigia
}

\author{
ОЛІЙНИК МАР’ ЯН ПЕТРОВИЧ \\ ГУБАРЬ ЛЮБОВ МАКСИМІВНА
}

OLIYNYK M.P., GUBAR L.M. (2019). Syntaxonomy of plant communities with diagnostic species of genus Elytrigia. Chornomors 'k. bot. z., 15 (1): 26-35. doi: 10.32999/ksu1990$553 \mathrm{X} / 2019-15-1-3$

Syntaxa diagnosed by species of Elytrigia Desv. (Elytrigia repens (L.) Nevski, E. elongata (Host) Nevski, E. intermedia (Host) Nevski, E. nodosa (Nevski) Nevski, E. pseudocaesia (Pach.) Prokud., E. trichophora (Link) Nevski, E. strigosa (M.Bieb.) Nevski, E. scythica (Nevski) Nevski), E. bessarabica (Săvul. \& Rayss) Prokud. are inventoried based on analysis of literature. Syntaxonomical content of the communities includes 48 associations from 25 alliances, 17 orders and 13 classes. A lot of the syntaxa are common and widespread (Elytrigio repentis-Aegopodietum podagrariae Tüxen 1967, Urtico dioicaeTanacetum vulgaris Kostylev in V. Solomakha et al. 1992, Artemisietum vulgaris R. Tüxen 1942, Elytrigio repentis-Robinietum pseudoacaciae Smetana, Derpoluk, Krasova 1997, etc.) or occur sporadically (Acini arvensis-Elytrigietum intermediae (Kukovitsa at al. 1994) Kukovitsa in V. Solomakha 1995, Salvio nemorosae-Elytrigietum intermediae Tyschenko, 1996, Goniolimoni taurici-Poetum angustifoliae Tyschenko 1996, Limonio-Festucetum pseudodalmaticae V. Solomakha et Shelyag-Sosonko 1984 etc.) in Ukraine. An absolute majority of the studied coenoses are in a state of dynamic expansion, with the exception of some relatively rare communities (Elytrigio trichophorae-Poetum angustifoliae (Kostylev et al. 1984) V. Solomakha 1995, Adonidi-Stipetum tirsae Didukh 1983, Drabo cuspidataePotentilletum geoidis Ryff 2000, Laserpitio hispidi-Heracleetum stevenii Korzhenevsky et Ryff 2002, etc.) that are constantly threatened by ecotope elimination. Most of the communities (23 associations) are dominated by Elytrigia repens that has wide ecological amplitude.

Key words: Elytrigia, species, syntaxonomy, Poaceae, flora of Ukraine

ОЛІйНИК М.П., ГУБАРЬ Л.М. (2019). Синтаксономія рослинних угруповань 3 діагностичними видами роду Elytrigia. Чорноморськ. бот. ж., 15 (1): 26-35. doi: 10.32999/ksu1990-553X/2019-15-1-3

Наведено результати інвентаризації синтаксонів, діагностичними видами яких $є$ види роду Elytrigia Desv. (Elytrigia repens (L.) Nevski, E. elongata (Host) Nevski, E. intermedia (Host) Nevski, E. nodosa (Nevski) Nevski, E. pseudocaesia (Pach.) Prokud., E. trichophora (Link) Nevski, E. strigosa (M.Bieb.) Nevski, E. scythica (Nevski) Nevski), E. bessarabica (Săvul. \& Rayss) Prokud. на підставі аналізу літературних джерел. Синтаксономічний склад досліджених рослинних угруповань нараховує 48 асоціацій, що належать до 25 союзів, 17 порядків та 13 класів. Значна частина синтаксонів рослинності належать до звичайних 3 частим (Elytrigio repentis-Aegopodietum podagrariae Tüxen 1967, Urtico dioicae-Tanacetum vulgaris Kostylev in V. Solomakha et al. 1992, Artemisietum vulgaris R. Tüxen 1942, Elytrigio repentis-Robinietum pseudoacaciae Smetana, Derpoluk, Krasova 1997 та ін.) та спорадичним (Acini arvensisElytrigietum intermediae (Kukovitsa at al. 1994) Kukovitsa in V. Solomakha 1995, Salvio nemorosae-Elytrigietum intermediae Tyschenko, 1996, Goniolimoni taurici-Poetum angustifoliae Tyschenko 1996, Limonio-Festucetum pseudodalmaticae V. Solomakha et Shelyag-Sosonko 1984 та ін.) поширенням на території України. Більшість досліджених фітоценозів відзначається експансивним динамічним станом. Винятком $\epsilon$ відносно рідкісні асоціації (Elytrigio trichophorae-Poetum angustifoliae (Kostylev et al. 1984) V. Solomakha 1995, Adonidi-Stipetum tirsae Didukh 1983, Drabo cuspidatae- 
Potentilletum geoidis Ryff 2000, Laserpitio hispidi-Heracleetum stevenii Korzhenevsky et Ryff 2002 та ін.) що перебувають під потенційною загрозою зникнення внаслідок елімінації їхніх екотопів. Едифікатором більшості рослинних угруповань (23 асоціації) є вид широкої екологічної амплітуди Elytrigia repens.

Ключові слова: види роду Elytrigia Desv., синтаксономія, родина Роасеае, флора України

ОЛИЙНЫК М.П., ГУБАРЬ Л.М. (2019). Синтаксономия растительных сообществ с диагностическими видами рода Elytrigia. Черноморськ. бот. ж., 15 (1): 26-35. doi: 10.32999/ksu1990-553X/2019-15-1-3

Приведены результаты инвентаризации синтаксонов, диагностическими видами которых являются виды рода Elytrigia Desv. (Elytrigia repens (L.) Nevski, E. elongata (Host) Nevski, E. intermedia (Host) Nevski, E. nodosa (Nevski) Nevski, E. pseudocaesia (Pach.) Prokud., E. trichophora (Link) Nevski, E. strigosa (M.Bieb.) Nevski, E. scythica (Nevski) Nevski), E. bessarabica (Săvul. \& Rayss) Prokud. на основании анализа литературных источников. Синтаксономический состав исследованных растительных сообществ насчитывает 48 ассоциаций, относящихся к 25 союзам, 17 порядкам и 13 классам. Значительная часть синтаксонов растительности принадлежат к обычным с частым (Elytrigio repentis-Aegopodietum podagrariae Tüxen 1967, Urtico dioicaeTanacetum vulgaris Kostylev in V. Solomakha et al. 1992, Artemisietum vulgaris R. Tüxen 1942, Elytrigio repentis-Robinietum pseudoacaciae Smetana, Derpoluk , Krasova 1997 и др.) и спорадическим (Acini arvensis-Elytrigietum intermediae (Kukovitsa at al. 1994) Kukovitsa in V. Solomakha 1995, Salvio nemorosae-Elytrigietum intermediae Tyschenko, 1996, Goniolimoni taurici-Poetum angustifoliae Tyschenko 1996, Limonio-Festucetum pseudodalmaticae V. Solomakha et Shelyag-Sosonko 1984 и др.) распространением на территории Украины. Большинство исследованных фитоценозов отмечается экспансивным динамическим состоянием. Исключением являются относительно редкие ассоциации (Elytrigio trichophorae-Poetum angustifoliae (Kostylev et al. 1984) V. Solomakha 1995, Adonidi-Stipetum tirsae Didukh 1983, Drabo cuspidatae-Potentilletum geoidis Ryff 2000, Laserpitio hispidi-Heracleetum stevenii Korzhenevsky et Ryff 2002 и др.) находящиеся под потенциальной угрозой исчезновения вследствие элиминации их экотопов. Эдификатором большинства растительных сообществ (23 ассоциации) является вид широкой экологической амплитуды Elytrigia repens.

Ключевые слова: виды рода Elytrigia Desv., синтаксономия, семейство Роасеае, флора Украинь

Genus Elytrigia Desv. is one of the biggest genera in the tribus Triticeae Dum. (Poaceae Barnh.). It has important significance for resource science. The species of the genus are widely used in agriculture (E. repens, E. elongata, E. intermedia) as fodder herbs and erosion control (E. repens, E. stipifolia (Czern. ex Nevski) Nevski). Elytrigia herbs for medicine (E. repens). According to recent data, the genus includes about 50 species. The phylogenetical relationship between these taxa are a subject for discussion [TSVELEV, 1976; MELDERIS et al., 1980; GUBAR, 2013].

Species of genus Elytrigia Desv. from the point of view of general biology and genetics of the plants are a discussion model for research of the processes of morphological variability, phenotypic plasticity, speciation, hybridization, biosystematics, phylogeny and population biology. Most of the problems of couch grass systematics and taxonomy are due to the fact that inter-species hybridization often happens among species of this genus and it also applies to the studied species of the genus Elytrigia of Ukrainian flora [KosTinA, AGAFONOV, 2002; DizKIRICI et al., 2010; TzVelev, Probatova, 2010]. The species of genus Elytrigia represent a compound, interspecific complex. Relations of natural ecological and geographical races of it (species, subspecies, varieties, hybrids) remain largely unexplained and deserve to be profoundly studied on a biosystematic and molecular phylogenetic level.

Relationship between plants underpin the organization and dynamic of phytocenosis. In recent years, the study of these processes is especially relevant. First and foremost, this is 
related to the growing needs of humankind in the development of conservation measures and sustainable use of vegetation (phytocenosis). An important object of such research is the species of the genus Elytrigia, which are widespread and are diagnostic for meadow, steppe, and ruderal groups. The signs and properties of plant populations-species of this genus, vary depending on the variability of environmental factors and spatial and temporal changes. Species populations differ in levels of succession and cenotic confinement. Thus, establishment of a range of cenosis in which these types play a dominant role is the first step on the way of the life strategy research of these species.

\section{Materials and methods}

Syntaxons identification and composition of vegetation prodromus were carried out on the basis of available literary sources on phytocenology, including contemporary classification schemes of vegetation in Ukraine [SOLOMAKHA et al., 1992; KOROTCHENKO, DiduKh, 1997; BABKO, 1999; KorotChENKo, FitsAILO, 2003; KuCHERAVYI et al., 2003; SOROKA, 2004; KUZYARIN, 2005; SOlOMAKHA, 2005; OsYPENKO, 2006; SLIVINSKA, Balashov, 2006; Chynkina, 2006; ChOKHA, 2006; MeleghiK et al., 2008; SoroKa, 2008; KorZhENEVSKy, KVITNYTSKa, 2009; PASHKEVyCH, Fitsailo, 2009; SKrobala, 2009; Golub et al., 2011; KuZEMKO, 2011; PARPAN, NESPliaK, 2011; DiduKh, VASHENYAK, 2012; KAHAlO, Resler, 2012; PARPAN, OlinYK, 2012; PASHKEVyCh, HAVRYlov, 2012; PARPAN, OlinYK, 2013A,B; DiduKh, 2014; KOLOMIYCHUK, MElEZHYK, 2014; KonOHRAI, 2014; Kramarets, BREDIHINA, 2014; OLIINYK, 2014; BREDIHINA, 2015; VorobJOV et al., 2015; BAgRiKovA, 2016; SHEVCHYK, KHOMIAK, 2016; OlinYK, 2017]. The higher syntaxonomic units are given in accordance with the latest edition of "Vegetation of Europe..." [MUCINA et al., 2016], the lower syntaxonomic units are rendered in accordance with the above mentioned Ukrainian and foreign sources and according to the International Code of Phytosociological Nomenclature [WEBER et al., 2000]. The names of taxons are given in accordance with «Vascular plants of Ukraine. A nomenclatural checklist» [MOSYAKIN, FEDORONCHUK, 1999].

By diagnostic, we mean the species which are characterized by high consistency in associations and most accurately reflect their appearance, structure and ecological properties of habitat. Diagnosticity of species of the genus Elytrigia in syntaxons, which are referred to in this article, is accepted by the above-cited literary sources [ALEXANDROVA, 1969].

The research subject is the classification of vegetation with the participation of species of the genus Elytrigia Desv.

\section{Results and disscusions}

According to different authors, nearly 50 species of the genus Elytrigia grow in subtropical and temperate climate areas [Prokudyn et al., 1977; Tsvelev, Probatova, 2010; GUBAR, 2013]. Twenty-four Elytrigia species were found in Europe including 16 specific to flora of Eastern Europe [MOSYAKIN, FEDORONCHUK, 1999].

Eight species of Elytrigia (Elytrigia repens (L.) Nevski, E. elongata (Host) Nevski, E. intermedia (Host) Nevski, E. nodosa (Nevski) Nevski, E. pseudocaesia (Pach.) Prokud., E. trichophora (Link) Nevski, E. strigosa (M.Bieb.) Nevski, E. scythica (Nevski) Nevski), Elytrigia (Săvul. \& Rayss) Prokud. of the flora of Ukraine are apparently diagnostic for 48 associations from 25 alliances, 17 orders and 13 vegetation classes of the following syntaxonomy:

Cl. Asplenietea trichomanis (Braun-Blanquet in Meier et Braun-Blanquet 1934) Oberdorfer 1977

Ord. Geranio robertiani-Asplenietalia trichomanis Ferrez ex Mucina et al. 2016

All. Drabo cuspidatae-Campanulion tauricae Ryff 2000

Ass. Drabo cuspidatae-Potentilletum geoidis Ryff 2000 (D.s. Elytrigia strigosa)

Cl. Drypidetea spinosae Quezel 1964 
Ord. Onosmo polyphyllae-Ptilostemonetalia Korzhenevsky 1990

All. Austrodauco-Salvion verticillati Korzhenevsky et Klyukin 1990

Ass. Lolio loliacei-Brassicetum tauricae Ryff 1999 (D.s. Elytrigia nodosa)

All. Ptilostemonion echinocephali Korzhenevsky 1990

Ass. Laserpitio hispidi-Heracleetum stevenii Korzhenevsky et Ryff 2002 (D.s. Elytrigia scythica)

All. Gypsophilo glomeratae-Cephalarion coriaceae Ryff in Golub et al. 2011

Ass. Elytrigio elongatae-Onobrychidetum pallasii Ryff 2004 (D.s. Elytrigia elongata)

Cl. Crataego-Prunetea Tüxen 1962

Ord. Paliuretalia Trinajstic 1978

All. Elytrigio nodosae-Rhuion coriariae Korzhenevsky et Ryff ex Didukh et Mucina 2014

Ass. Seseli dichotomi-Rhuetum coriariae Didukh et Mucina 2014 (D.s. Elytrigia nodosa)

Ass. Melico tauricae-Rhuetum coriariae Didukh et Mucina 2014 (D.s. Elytrigia nodosa)

Cl. Molinio-Arrhenatheretea Tx. 1937

Ord. Molinietalia caeruleae Koch 1926

All. Deschampsion cespitosae Horvatić 1930

Ass. Agropyro-Alopecuretum pratensis Moraveč 1965 (D.s. Elytrigia repens)

Ord. Potentillo-Polygonetalia avicularis Tx. 1947

All. Potentillion anserinae Tx. 1947

Ass. Glechomo hederaceae-Potentilletum reptantis Levon 1997 (D.s. Elytrigia repens)

Cl. Festuco-Brometea Braun-Blanquet et Tüxen ex Soó 1947

Ord. Festucetalia valesiacae Soó 1947

All. Festucion valesiacae Klika 1931

Ass. Acini arvensis-Elytrigietum intermediae (Kukovitsa et al. 1994) Kukovitsa in V. Solomakha 1995 (D.s. Elytrigia intermedia)

Ass. Salvio nemorosae-Elytrigietum intermediae Tyschenko 1996 (D.s. Elytrigia intermedia)

All. Achilleo setaceae - Poenion angustifoliae Tkachenko \& al. 1987

Ass. Medicagini romanicae-Poetum angustifoliae Tkachenko, Movchan et V. Solomakha 1987 (D.s. Elytrigia repens)

Ass. Achilleo setaceae-Poetum angustifoliae Marjushkina et V. Solomakha 1986 (D.s. Elytrigia repens)

Ass. Elytrigio trichophorae-Poetum angustifoliae (Kostylev et al. 1984) V. Solomakha 1995 (D.s. Elytrigia trichophora)

Ass. Goniolimoni taurici-Poetum angustifoliae Tyschenko 1996 (D.s. Elytrigia elongata)

All. Artemisio tauricae-Festucion Korzhenevsky et Klyukin 1991

Ass. Arenario uralensis-Elytrigietum pseudocaesiae Solomakha et al. 2005 (D.s. Elytrigia pseudocaesia)

All. Adonido vernalis-Stipion tirsae Didukh in Didukh et Mucina 2014

Ass. Adonido vernalis-Stipetum tirsae Didukh in Didukh et Mucina 2014 (D.s. Elytrigia trichophora)

All. Artemisio marschallianae-Elytrigion intermediae Korotchenko et Didukh 1997

Ass. Astragalo dasyanthi-Elytrigietum intermediae Korotchenko et Didukh 1997 (D.s. Elytrigia intermedia)

Cl. Pegano harmalae-Salsoletea vermiculatae Braun-Blanquet et O. de Bolòs 1958 
Ord. Helichryso stoechadis-Santolinetalia squarrosae Peinado et Martínez-Parras 1984

All. Atraphaco-Capparidion Korzhenevsky 1988

Ass. Atraphaco-Capparidetum Korzhenevsky et Klyukin 1988 (D.s. Elytrigia elongata)

Cl. Festuco-Puccinellietea Soó ex Vicherek 1973

Ord. Artemisio santonicae-Limonietalia gmelinii Golub et V. Solomakha 1988

All. Plantagini salsae-Artemision santonicae Shelyag-Sosonko et Solomakha in

Lysenko, Mucina et Iakushenko 2011

Ass. Limonio alutaceae-Elytrigietum elongatae Bairak 1997 (D.s. Elytrigia elongata)

Ass. Artemisio santonicae-Elytrigietum elongatae Dubyna, Neuhäuslova, Shelyag-

Sosonko 1995 (D.s. Elytrigia elongata)

Ass. Agropyro elongati-Inuletum salicinae Serbanescu 1965 (D.s. Elytrigia elongata)

Ass. Agropyretum elongatae Serbanescu 1965 (D.s. Elytrigia elongata)

Ass. Limonio meyeri-Elytrigetum elongatae Tyshchenko 1996 (D.s. Elytrigia elongata)

Ord. Festuco valesiacae-Limonietalia gmelinii Mirkin in Golub et Solomakha 1988

All. Limonio-Festucion V. Solomakha et Shelyag-Sosonko 1984

Ass. Limonio-Festucetum pseudodalmaticae V. Solomakha et Shelyag-Sosonko 1984 (D.s. Elytrigia elongata)

All. Diantho-Milion vernale Umanets et I. Solomakha 1988

Ass. Cardario-Stipetum capillatae Umanets et V. Solomakha 1988 (D.s. Elytrigia pseudocaesia)

All. Camphorosmo-Agropyrion desertorum Korzhenevsky et Klyukin in Golub et al. 2005

Ass. Meliloti-Elytrigietum repensii Korzhenevsky et Klyukin 1990 (D.s. Elytrigia repens)

Cl. Juncetea maritimi Braun-Blanquet in Braun-Blanquet et al. 1952

Ord. Juncetalia maritimi Braun-Blanquet ex Horvatić 1934

All. Juncion maritimi Braun-Blanquet ex Horvatić 1934

Ass. Plantagini salsa-Juncetum maritimi Shelyag-Sosonco et V. Solomakha 1987 (D.s. Elytrigia bessarabica)

Ass. Plantagini-Limonietum Westh. Et Segal 1961 (D.s. Elytrigia elongata)

Cl. Crypsietea aculeatae Vicherek 1973

Ord. Crypsietalia aculeatae Vicherek 1973

All. Lepidion latifolii Golub et Mirkin in Golub 1995

Ass. Cynancho acuti-Lepidietum latifolii Dubyna, Neuhäuslová et Shelyag-Sosonko 1994 (D.s. Elytrigia elongata)

Cl. Robinietea Jurko ex Hada c et Sofron1980

Ord. Chelidonio-Robinietalia pseudoacaciae Jurko ex Hadac et Sofron 1980

All. Chelidonio majoris-Robinion pseudoacaciae Hadac et Sofron ex Vitkova in Chytrý 2013

Ass. Elytrigio repentis-Robinietum pseudoacaciae Smetana, Derpoluk, Krasova 1997

(D.s. Elytrigia repens)

Cl. Sisymbrietea Gutte et Hilbig 1975

Ord. Sisymbrietalia sophiae J. Tüxen ex Görs 1966

All. Sisymbrion officinalis Tüxen et al. ex von Rochow 1951

Ass. Matricarietum perforatae Kepczynska 1975 (D.s. Elytrigia repens)

Ass. Diplotaxio muralis-Erodietum cicutarii Bagrikova 2002 (D.s. Elytrigia repens)

Cl. Artemisietea vulgaris Lohmeyer et al. in Tüxen ex von Rochow 1951

Ord. Agropyretalia intermedio-repentis T. Müller et Görs 1969

All. Convolvulo arvensis-Agropyrion repentis Görs 1967 
Ass. Convolvulo-Agropyretum repentis Felföldy (1942) 1943 (D.s. Elytrigia repens)

Ass. Agropyretum repentis Görs 1966 (D.s. Elytrigia repens)

Ass. Cardario-Agropyretum Th. Müller et. Görs 1969 (D.s. Elytrigia repens)

Ass. Elytrigio nodosae-Xeranthemetum cylindracei Levon 1997 (D.s. Elytrigia nodosa)

Ass. Elytrigio repentis-Lycietum barbati Kostylev in V. Solomakha et al. 1992 (D.s. Elytrigia repens)

Ass. Convolvulo-Brometum inermitis Elias 1979 (D.s. Elytrigia repens)

Ord. Onopordetalia acanthii Braun-Blanquet et Tüxen ex Klika et Hadac 1944

All. Onopordion acanthii Braun-Blanquet et al. 1936

Ass. Carduo acanthoidis-Onopordetum acanthii Soó ex Jarolímek et al. 1997 (D.s. Elytrigia repens)

Cl. Epilobietea angustifolii Tüxen et Preising ex von Rochow 1951

Ord. Arctio lappae-Artemisietalia vulgaris Dengler 2002

All. Arction lappae Tüxen 1937

Ass. Arctietum lappae Felföldy 1942 (D.s. Elytrigia repens)

Ass. Arctio-Artemisietum vulgaris Oberdorfer ex Th. Müller 1972 (D.s. Elytrigia repens)

Ass. Artemisietum vulgaris R. Tüxen 1942 (D.s. Elytrigia repens)

Ass. Urtico dioicae-Tanacetum vulgaris Kostylev in V. Solomakha et al. 1992 (D.s. Elytrigia repens)

Ass. Aristolochio-Agropyretum repentis Bagrikova 2002 (D.s. Elytrigia repens)

Ass. Elytrigio repentis-Poetum compressae Smetana, Derpoluk, Krasova 1997 (D.s. Elytrigia repens)

Ass. Balloto nigrae-Leonuretum cardiacae Tüxen et von Rochow 1942 (D.s. Elytrigia repens)

Ass. Chenopodio-Ballotetum nigrae Tüxen 1931 (D.s. Elytrigia repens)

Ord. Circaeo lutetianae-Stachyetalia sylvaticae Passarge 1967

All. Aegopodion podagrariae Tüxen 1967

$\begin{array}{llll}\text { Ass. Elytrigio repentis-Aegopodietum podagrariae Tüxen } 1967 & \end{array}$ (D.s. Elytrigia repens)

Elytrigia repens is a species of wide ecological amplitude: it is a heliophyte that grows in hygrophytic, mesophytic, halomesophytic and xerophytic ecotopes [PROKUDYN et al., 1977]. It is a part of 23 associations belonging to 10 alliances, 10 orders and 6 classes. It is an environmental edaphicator of meadow steppe coenoses (Festuco-Brometea), mesophytic communitites on salinized substrates of fluctuating humidity (Festuco-Puccinellietea), anthropogenically transformed arboreous coenoses (Robinietea, Epilobietea angustifolii) and synanthropic communities (Artemisietea vulgaris, Sisymbrietea).

Elytrigia elongata is a mesoxerophyte and a heliophyte [PROKUDYN et al., 1977]. The species is found in 11 associations from 7 alliances, 7 orders and 6 classes. It is an environmental engineer of halophytic communities on salt marshes, on the sands of lower Dnieper, banks and islands and in general on the littoral of Ukrainian mainland (FestucoPuccinellietea, Crypsietea aculeatae); xerophytic shrubberies on gleysols (Drypidetea spinosae); meadow steppe coenoses (Festuco-Brometea) and communities of Mediterranean mountain steppe, e.g. the Crimean mountains (Pegano harmalae-Salsoletea vermiculatae).

Elytrigia intermedia is a xeromesophyte and heliophyte [PROKUDYN et al., 1977]. It participates in 3 associations from 2 alliances, 2 orders and 1 classes. It grows in meadow steppe coenoses (Festuco-Brometea), in xerophilic shrubberies on gleysols (Drypidetea spinosae) occurring in steppes, including sandy areas, on steppe slopes, on chalks, limestone and loess outcrops, on sandstone, forest glades and edges, in thickets, on jajlas (plateaus), on 
the edges of shelter belts and on roadsides. It grows copiously on rocky substrates of petrophilous steppe and makes dense stands in areas with disturbed vegetation.

Elytrigia nodosa is a xerophyte and a heliophyte [PROKUDYN et al., 1977]. It is the engineer of 4 associations from 3 alliances, 3 orders and 3 classes. A typical species for open dry slopes of gravelly screes, seashore clayey banks of the lower belt of the Southern Crimea (Crataego-Prunetea). On grassless slopes it sometimes grows in solid monostand shrub-like communities or thin communities with large tussocks. It also forms xerophytic shrubberies on gleysols (Drypidetea spinosae) and sinanthropic communities (Artemisietea vulgaris).

Elytrigia pseudocaesia is a xeromesophyte and a heliophyte [PROKUDYN et al., 1977]. It is found in 2 associations from 2 alliances, 2 orders and 2 classes, is a common dominant species of forbs-and-grasses meadows in brakish and briny oval depressions (FestucoPuccinellietea) and in steppe zone grasslands (Festuco-Brometea).

Elytrigia trichophora is a xeromesophyte and a heliophyte [PROKUDYN et al., 1977] edificator of 2 associations belonging to 2 alliances, 1 order and 1 class. It tends towards washed-out chernozems, kastanozems, rocky substrates (gravelly soils, rocks, embankments). It makes up communities of forest edges, dry, steppe-ish glades and slopes (FestucoBrometea).

Elytrigia strigosa is a xerophyte and a heliophyte [PROKUDYN et al., 1977]. It participates in 1 association (and so 1 alliance, 1 order and 1 class) and does not tolerate developed greensward. It is a common species of thinned herbaceous layer at open dry rocky slopes, rocks, embankments and weakly developed gravelly soils on jajlas and in the upper woody belt (in pine and beech forests) of the Crimean Mountains (Asplenietea trichomanis).

Elytrigia scythica is a xerophyte and a heliophyte [PROKUDYN et al., 1977], occurring in a single association. It is a diagnostic species of xerophilyc shrubberies on gleysols (Drypidetea spinosae).

Elytrigia bessarabica is a psamophyte and a heliophyte [PROKUDYN et al., 1977], occurring in a single association. It grows in seaside sands and sand and shell rock floats of the Black and Azov sea littoral fringe. It is a diagnostic species of a group of the sea damp meadows on the moderately and severely saline soils of the northern Black Sea coast.

\section{Conclusions}

All in all, our inventory of syntaxa diagnosed by species of Elytrigia (Elytrigia repens, E. elongata, E. intermedia, E. nodosa, E. pseudocaesia, E. trichophora, E. strigose, E. scythica, E. bessarabica literature data revealed that the vegetation of studied communities belongs to 48 associations from 25 alliances, 17 orders and 13 classes. Nine associations occur only in Ukraine (Drabo cuspidatae-Potentilletum geoidis, Lolio loliacei-Brassicetum tauricae, Laserpitio hispidi-Heracleetum stevenii, Elytrigio elongatae-Onobrychidetum pallasii, Seseli dichotomi-Rhuetum coriariae, Melico tauricae-Rhuetum coriariae, Arenario uralensis-Elytrigietum pseudocaesiae, Adonidi-Stipetum tirsae, Cardario-Stipetum capillatae). Other associations have wider geographic ranges.

Elytrigia repens is a diagnostic species in most communities (23 associations) and has a wide ecological amplitude. Other species take part in 1 to 11 associations.

A lot of the syntaxa are common and widespread (Elytrigio repentis-Aegopodietum podagrariae, Urtico dioicae-Tanacetum vulgaris, Artemisietum vulgaris, Elytrigio repentisRobinietum pseudoacaciae etc.) or occur sporadically (Acini arvensis-Elytrigietum intermediae, Salvio nemorosae-Elytrigietum intermediae, Goniolimoni taurici-Poetum angustifoliae, Limonio-Festucetum pseudodalmaticae etc.) in Ukraine. An absolute majority of the studied coenoses are in a state of dynamic expansion, with the exception of some relatively rare communities (Elytrigio trichophorae-Poetum angustifoliae, Adonidi-Stipetum tirsae, Drabo cuspidatae-Potentilletum geoidis, Laserpitio hispidi-Heracleetum stevenii etc.) that are constantly threatened by ecotope elimination. 
We consider the syntaxonomy of various species of Elytrigia to be insufficiently studied due to problematic structure of the genus, difficulties in species identification and absence of species-specific data on ecological strategies; we plan to address these questions in further research.

\section{References}

ALEXANDROVA V.D. (1969). Klassifikatsiya rastitelnosti. Obzor printsipov klassifikatsii i klassifikatsionnyih sistem $v$ raznyih geobotanicheskih shkolah. L.: Nauka: 276 p.

BAGRIKOVA N.A. (2016). Study of synanthropic vegetation of the Crimean peninsula according to ecologicalfloristic approach: state of matter, communities classification and perspective of the researches. Works of Nikit. Botan. Gard, 143: 25-58. (in Ukrainian)

BREDIHINA J.L. (2015) Spontaneous vegetation in Melitopol town: syntaxonomy, phytomeliorative significance and directions of optimization. Lviv: National Forestry University of Ukraine (in Ukrainian).

BABKO I.A. (1999). Steppe plant caver differentiation of the Left-Bank Forest-Steppe south part of Ukraine. Kyev: M.G. Kholodny Institute of Botany of the National Academy of Sciences of Ukraine (in Ukrainian).

CHOKна O.V. (2006). Ecological peculiarities of Kyiv Turf-Grasses vegetation. Ukr. Phytosociol. Collect., 24: 53-61. (in Ukrainian)

Chinkina T. (2006). Wetland vegetation syntaxonomic diagram of the river Dnieper river estuary region. Visnyk of L'viv Univ., Biology series, 42: 32-37. (in Ukrainian)

DIDUKH YA.P. (2014). Synergetic approaches to the assessment of landscare and ecological differentiation of Karabi Plateau (Mountain Crimea). Ukr. Geogarph. J., 1: 36-43. (in Ukrainian)

DIDUKH Y.P., MUCINA L. (2014). Validation of the name of some syntaxa of Crimean vegetation. Lazaroa, 35: $181-190$

DiDUKH YA.P., VASHENYAK YU.A. (2012). Steppe vegetation in Central Podillya. Ukr. Bot. J., 69(6): $789-817$. (in Ukrainian)

Dubyna D.V., DZIUBA T.P., NeuhäUslova Z. (2007). Halophytic vegetation. Classes Bolboschoenetea maritime, Festuco-Puccinellietea, Molinio-Juncetea, Crypsietea aculeatae, Thero-Salicornietea strictae, Salicornietea fruticosae, Juncetea maritime. Edit.-in-chief Yu.R. Shelyag-Sosonko. Vegetation of Ukraine. K.: Phytosociocentre: 315 p. (in Ukrainian)

DiZKIRICI A., KAYA Z., CABI E., DOGAN M. (2010). Phylogenetic relationships of Elymus L. and related genera (Poaceae: Triticeae Dumort.) based on the nuclear ribosomal internal transcribed spacer sequences. Turk. J. of Botany, 3(6): 467-478.

Golub V.B., GReChUSHKINA N.A., SOROKIN A.N., NIKOLAYCHUK L.F. (2011). Plant communities of the class Onosmato polyphyllae-Ptilostemonetea Korzhenevsky 1990 on the territory of the Black Sea coast of the Caucasus and the Crimean peninsula. Vegetation of Russia, 17-18: 3-16. (in Russia)

Gubar L.M. (2013). Rody Agropyron Gaertn., Elymus L., Elytrigia DESV., Leymus Hochst i Psathyrostachys Nevski (Roaceae) flory Ukrainy. II Vseukrainska naukovo-praktychna konferentsiia "Suchasni problemy pryrodnychykh nauk ta metodyky vykladannia" (do 80 richnytsi vid dnia stvorennia pryrodnycho-heohrafichnoho fakultetu): Materialy dopovidei / za zahalnoiu redaktsiieiu I.V. Marysovoi. Nizhyn: NDU imeni Mykoly Hoholia: 21-22 (in Ukrainian).

KAHALO O.O., RESLER I.YA. (2012). Vegetation of regional landscape park "Ravs'ke Roztochia” (Lviv region) - previous syntaxonomical assessment. Scientific principles of biodiversity conservation, 3(10): 5976. (in Ukrainian)

KolOMiYCHUK V.P., MelEZHYK O.V. (2014). Vegetation syntaxonomy of the sea of Azov landslide coasts. Visnyk of Zaporizhzhya National University. Biological Sciences, 1: 173-182 (in Ukrainian).

KONOHRAI V. (2014). Syntaksonomiia ta osoblyvosti terytorialnoho rozpodilu roslynnosti terytorii Kremenchutskoho vodoskhovyshcha. Visnyk Lviv. un-tu. Seriia biolohichna, 67: 156-172. (in Ukrainian)

KoRotchenko I.A, DidUKH Y.P. (1997). The steppe vegetation of the southern part of the Left-Bank ForestSteppe of the Ukraine. II. Class Festuco-Brometea. Ukr. Phytosociol. Collect., 1(6): 20-39. (in Ukrainian)

Korotchenko I., FitsAilo T. (2003). The steppe vegetation of Kyiv platean region. Nauk. zap. NaUKMA. Biol. ta ekol., 21: 20-36. (in Ukrainian)

KorZHENEVSKY V.V., KVITnYTSKA A.A. (2009). Phytoindication of mud volcanos of the Crimea. Pryrodnychyi almanakh (biolohichni nauky), 12: 155-165. (in Ukrainian)

Kostina E.V., AgAFOnOV A.V. (2002). Electrophoretic study of polymorphism of grain storage proteins and histon H1 in Elytrigia repens (Poaceae). Botanical journal, 87(3): 106-115. (in Russian)

Kramarets V., BredihinA J.U. (2014). Syntaxonomy of spontaneous vegetation in the Melitopol region. Proceedings of the Forestry Academy of Sciences of Ukraine, 12: 38-43. (in Ukrainian) 
KucheraVyi V., DANYlyk I., SkRobala V., DANYLYK R. (2003). Urban transformation of vegetation cover in the upper part of the Dnister river basin. Pratsi Naukovoho tovarystva im. Shevchenka. Ekolohichnyi zbirnyk. Ekolohichni problemy Karpatskoho rehionu: 81-93. (in Ukrainian)

KuZEMKo A.A. (2009). Meadow vegetation. Molinio-Arrhenatheretea class. Edit.-in-chief Yu.R. ShelyagSosonko. Vegetation of Ukraine. K.: Phytosociocentre: 376 p. (in Ukrainian)

KuZEMKo A.A. (2011). Meadow-steppe vegetation of the National Dendrological Park Sofiyivka of the NAS of Ukraine and it's changes as a result of anthropogenic pressure. Plant introduction, 2: 19-30. (in Ukrainian)

KUZYARIN A. (2005). The The syntaxonomy of ruderal vegetation of flood plain ecosystems in the Western Bug river basin. Proc. of the State Nat. Hist. Museum, 21: 29-52. (in Ukrainian)

MELDERIS A., ET AL. (1980). Flora Europaea Vol. 5 Alismataceae to Orchidaceae (Monocotyledones). Cambridge, UK: Cambridge University Press: 192-198.

MeleghiK O., Solomakha V., Solomakha T. (2008). Structure and adjective vegetations of grass-plots in Kyiv. Thaiszia. J. Bot., Kosice, 18: 69-74.

MOSYAKIN S., FEDORONCHUK M. (1999). Vascular plants of Ukraine: a nomenclatural checklist. Kiev: 345 p.

Mucina L., BÜltmann H., Dierßen K., Theurillat J.-P., Raus T., ČARni A., Šumberová K., Willner W., Dengler J., Gavilán García R., Chytrý M., Hájek M., Di Pietro R., iakushenko D., Pallas J., Daniëls F.J.A., Bergmeier E., SANTOS Guerra A., ERMaKov N., VAlachoviČ M., SChaminÉE J.H.J., LySENKo T., DidukH Y.P., PignATti S., RodWEll J.S., CAPElO J., Weber H.E., Solomeshch A., Dimopoulos P., Aguiar C., Hennekens S.M., TichÝ L. (2016). Vegetation of Europe: hierarchical floristic classification system of vascular plant, bryophyte, lichen, and algal communities. Applied Vegetation Science, 19(1): 1-783. doi: 10.1111/avsc. 12257

OLIJNYK M.P. (2014). Dynamika biomorfnoi struktury florokompleksiv perelohiv na stadiiakh vtorynnoi suktsesii. Materialy I Vseukrainskoi naukovo-praktychnoi konferentsii molodykh vchenykh ta studentiv z mizhnarodnoiu uchastiu Dnipropetrovsk: 227-229. (in Ukrainian)

OLIJNYK M.P. (2017) . Secondary succession of vegetation on abandoned lands of Transdnister Podillya. Ukr. Bot. J., 74(3): 276-283 (in Ukrainian). doi: 10.15407/ukrbotj74.03.276

OSYPENKo V.V. (2006). Spontaneous vegetation of Cherkasy. Kyiv: Taras Shevshenko Kyiv National University (in Ukrainian).

PARPAN V.I. OLIJNYK M.P. (2012). The alien fraction of the urban flora of the Prednistrovian Podillya old-fields ecosystems. Ecology and noospherology, 23 (3-4): 116-119. (in Ukrainian)

PARPAN V.I., NESPLIAK O.S. (2011). The vegetation classification of the asheslag dumps of Burshtynska TEPS. Scientific Bulletin of National Forestry University of Ukraine: Collection of scientific works, NLTUU, 21(5): 82-87. (in Ukrainian)

PARPAN V., OLIJNYK M. (2013A). Direction of flora synanthropization changing on the fallows of Prednistrovian Podillya. Visnyk of the Lviv University: (Series Biology), 63: 133-140. (in Ukrainian)

PARPAN V.I., OLIJNYK M.P. (2013B). Arboraceous species natural restoration on the Pre-Dnister Podillya fallows. Scientific Bulletin of National Forestry University of Ukraine: Collection of scientific works, NLTUU, 23(14): 8-15. (in Ukrainian)

PASHKEVYCH N.A., HAVRYlov S.O. (2012). Transformation of Vegetation Cover of Abandoned Fields in Shatsky National Nature Park. Nature of Western Polissia and surrounding Areas, 9: 139-142. (in Ukrainian)

PASHKEVYCH N.A., FITSAILO T.V. (2009). Synanthropic vegetation of transformed biotopes of Chernigiv region. Ukr. Bot. J, 66(2): 213-219. (in Ukrainian)

ProkUdyn Yu.N., Vovk A.H., Petrova O.A. (1977). Zlaki Ukrainy. K: Nauk. dumka, 520 p. (in Ukrainian)

SHEVCHYK O.O., KHOMIAK I.V. (2016). Otsinka florystychnykh resursiv pryrodnykh ekosystem dolyny richky Sluch. Tezy Vseukrainskoi naukovo-praktychnoi konferentsii "Stalyi rozvytok krainy v ramkakh Yevropeiskoi intehratsii”, 27 zhovtnia 2016 roku. Zhytomyr: 69-70. (in Ukrainian)

SKROBALA V. (2009). Multidimensional typology of forest vegetation of the Ukraine: a regional level. Scientific Bulletin of National Forestry University of Ukraine: Collection of scientific works, NLTUU, 50: 4451. (in Ukrainian)

SLIVINSKA K.A., BALASHOV L.S. (2006). Phytocoenotic composition of Przewalski's horse (Equus przevalskii Poljakov, 1881) feeding grounds in the Chornobyl exclusion zone. Ukr. Bot. J, 63(1): 22-30. (in Ukrainian)

SOLOMAKHA I.V. (2005). Syntaxonomy of vegetation of forests and shrubs of the Northern Black Sea region. Biological systems, 7(2): 236-243. (in Ukrainian)

SolomaKhA V.A. (2008). Syntaksonomiia roslynnosti Ukrainy. Tretie nablyzhennia. Monohrafiia. Kyiv: Fitosotsiotsentr, 296 p. (in Ukrainian)

Solomakha V.A., Kostylov O.V., Sheliah-Sosonko YU.R. (1992). Synantropna roslynnist Ukrainy. Kyiv: Naukova dumka, 252 p. (in Ukrainian)

SOROKA M.I. (2004). Flora and vegetation of natural reservation "Roztocze". Scientific Bulletin of USUWFT, 14(8): 170-179. (in Ukrainian) 
SOROKA M.I. (2008). Roslynnist Ukrainskoho Roztochchia. Lviv: Svit, 434 p. (in Ukrainian)

TSVELEV N.N. (1976). Zlaki SSSR. L.: Nauka, 788 p. (in Russian)

Tzvelev N.N., Probatova N.S. (2010). The genera Elymus L., Elytrigia Desv., Agropyron Gaertn., Psathyrostachys Nevski and Leymus Hochst. (Poaceae: Triticeae) in the flora of Russia. V.L. Komarov Memorial Lectures, 57: 5-102. (in Russian)

Vorobjov Ye.O., OLIJNYK M.P., SOlOMAKHA I.V. (2015). Syntaxonomy groups in small deciduous forests overgrown fallow. Biological bulletin of Bogdan Chmelnitskiy Melitopol state pedagogical university. 5(2): 54-63. (in Ukrainian)

Weber H. E., Moravec J. \& Theurillat J.-P. (2000). International Code of Phytosociological Nomenclature. 3rd edition. Journal of Vegetation Science, 11: 739-768.

Рекомендує до друку

Отримано 14.04.2018

Мойсієнко I.I.

Адреси авторів:

М.П. Олійник,

Л.М. Губарь

ДУ «Інститут еволючійної екології

НАН України»

вул. акад. Лебедєва, 37

Київ, 03143

Україна

e-mail: marianolijnyk@gmail.com
Authors' addres:

M.P. Olijnyk

L.M. Gubar

Institute for evolutionary ecology of the National

Academy of Sciences of Ukraine

37, Lebedeva str.

Kyiv, 03143

Ukraine

e-mail: marianolijnyk@gmail.com 